2007-01-01

\title{
A New Approach to the Toxicity Testing of Carbon-based Nanomaterials: the Clonogenic Assay
}

\author{
Eva Herzog \\ Technological University Dublin \\ Alan Casey \\ Technological University Dublin, alan.casey@tudublin.ie \\ Fiona Lyng \\ Technological University Dublin, fiona.lyng@tudublin.ie
}

See next page for additional authors

Follow this and additional works at: https://arrow.tudublin.ie/nanolart

Part of the Physics Commons

\section{Recommended Citation}

Herzog, E. et al. (2007) A new approach to the toxicity testing of carbon-based nanomaterials: the clonogenic assay. Toxicology Letters, Vol. 174, Issues 1-3, pp. 49-601. doi:10.1016/j.toxlet.2007.08.009

This Article is brought to you for free and open access by the NanoLab at ARROW@TU Dublin. It has been accepted for inclusion in Articles by an authorized administrator of ARROW@TU Dublin. For more information, please contact arrow.admin@tudublin.ie, aisling.coyne@tudublin.ie,gerard.connolly@tudublin.ie.

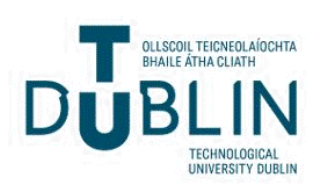




\section{Authors}

Eva Herzog, Alan Casey, Fiona Lyng, Gordon Chambers, Hugh Byrne, and Maria Davoren 


\title{
A new approach to the toxicity testing of carbon-based nanomaterials-The clonogenic assay
}

\author{
Eva Herzog ${ }^{\mathrm{a}, *}$, Alan Casey ${ }^{\mathrm{b}}$, Fiona M. Lyng ${ }^{\mathrm{a}}$, Gordon Chambers ${ }^{\mathrm{b}}$, \\ Hugh J. Byrne ${ }^{\mathrm{b}}$, Maria Davoren ${ }^{\mathrm{a}}$ \\ ${ }^{a}$ Radiation and Environmental Science Centre, Focas Institute, Dublin Institute of Technology, Kevin Street, Dublin 8, Ireland \\ ${ }^{\mathrm{b}}$ Physics of Molecular Materials Group, Focas Institute, Dublin Institute of Technology, Kevin Street, Dublin 8, Ireland
}

Received 21 August 2007; accepted 22 August 2007

Available online 26 August 2007

\begin{abstract}
The cellular toxicity of three types of carbon nanoparticles, namely HiPco ${ }^{\circledR}$ single-walled carbon nanotubes (SWCNT), arc discharge SWCNT and Printex 90 carbon black nanoparticles, was studied on three different cell models including the human alveolar carcinoma epithelial cell line (A549), the normal human bronchial epithelial cell line (BEAS-2B) and the human keratinocyte cell line $(\mathrm{HaCaT})$ using the clonogenic assay. Carbon nanomaterials are known to interact with colorimetric indicator dyes frequently used in cytotoxicity assays. By employing the clonogenic assay, any such interactions could be avoided, allowing a more reliable method for the in vitro toxicity assessment of carbon-based nanoparticles. It could be shown that the toxicity of as produced SWCNT samples differs between cell lines and the SWCNT production method used, with HiPco ${ }^{\circledR}$ SWCNT samples being more reactive compared to arc discharge produced SWCNT samples, both eliciting a stronger cytotoxic response than carbon black. Furthermore, it was possible to distinguish between effects on cell viability and cell proliferation by including colony size as an additional endpoint in the clonogenic assay. All three particle types were highly effective in inhibiting cell proliferation in all three cell lines, whereas only $\mathrm{HaCaT}$ and BEAS-2B cells also showed decreased cell viability.
\end{abstract}

(c) 2007 Elsevier Ireland Ltd. All rights reserved.

Keywords: Single-walled carbon nanotubes; Carbon black; Cytotoxicity; Colony size; Pulmonary toxicity; Dermal toxicity

\section{Introduction}

Carbon-based nanomaterials, including fullerenes, single and multi-walled carbon nanotubes and carbon nanoparticles, are currently one of the most attractive nanomaterials from an applications perspective (Huczko, 2002). Since their discovery in 1991 by Sumio Iijima, carbon nanotubes have been intensively studied (Iijima, 1991). Their extraordinary electronic and

\footnotetext{
* Corresponding author.

E-mail address: eva.herzog@ dit.ie (E. Herzog).
}

mechanic properties point towards a great variety of potential future applications (The Royal Society, 2004) and in the last 2 years, synthesis and yield of carbon nanotubes have significantly increased, resulting in increased exposure risk (Magrez et al., 2006). Due to the rising global production and proposed applications, including polymer composites (Miyagawa et al., 2005), electronics (De Jonge and Bonard, 2004) and drug delivery (Bianco et al., 2005), considerable concern has been raised regarding the health risks of these engineered nanoparticles (Maynard et al., 2004; Oberdörster et al., 2005; The Royal Society, 2004). Lung and skin are regarded as the two main potential exposure sites 
during manufacture and material handling (Shvedova et al., 2003; Smart et al., 2006). The high ratio between length and diameter of carbon nanotubes and their low solubility in aqueous media makes them potentially biopersistent and may lead to toxic effects similar to those seen with other fibrous particles such as asbestos (Donaldson et al., 2006; Maynard et al., 2004; Muller et al., 2006).

Acute toxicity of SWCNT has recently been described in several publications using a variety of cell types (Jia et al., 2005; Manna et al., 2005; MonteiroRiviere et al., 2005; Muller et al., 2006; Shvedova et al., 2003). However, the in vitro cytotoxicity assessment of carbon-based nanomaterials has been problematic due to their adsorptive nature. Many of the most commonly used cytotoxicity screening assays are based on fluorescence or absorbance measurements following toxicant exposure and incubation with a colorimetric indicator dye of choice. Interactions between single-walled carbon nanotubes (SWCNT) and other carbon-based nanomaterials with a number of these indicator dyes, such as 3-(4,5-dimethylthiazol-2-yl)-2,5-diphenyltetrazolium bromide (MTT), 2-(4-iodophenyl)-3-(4-nitrophenyl)-5(2,4-disulfophenyl)-2H-tetrazolium (WST-1), Neutral Red and Alamar Blue ${ }^{\mathrm{TM}}$ have recently been identified and demonstrated (Casey et al., 2007a; Hurt et al., 2006; Monteiro-Riviere and Inman, 2006; WörleKnirsch et al., 2006). These interactions are most likely interpretable as a physisorption of dye molecules through van der Waals forces with the overall effect of quenched fluorescence and/or absorbance of the dyes. This potentially leads to false readings and misinterpretation of particle toxicity, making these assays inappropriate for quantitative assessment of carbon nanomaterial toxicity and highlights the urgent need for the development and application of alternative screening techniques (Casey et al., 2007a,b; Davoren et al., 2007). The development and validation of methods to evaluate the toxicity of engineered nanomaterials is also regarded as one of the main future challenges relevant to the safety of nanotechnology (Maynard et al., 2006).

In this study, the clonogenic assay is used as an alternative method which avoids the use of any colorimetric or fluorescent indicator dye, thus eliminating the risk of interactions and allowing the assessment of true cytotoxicity. The clonogenic assay, also called colony formation assay, is an in vitro cell survival based assay measuring the ability of a single cell to form a colony. It was first described in 1956 by Puck and Markus (1956). Since this time, it has been used in a variety of studies with many different cell types to detect cells that retained the capacity for producing a large number of progeny after treatments that can cause reproductive death as a result of damage to chromosomes, apoptosis, etc. (Brown and Attardi, 2005). So far, it is the method of choice in the area of oncological research to determine reproductive cell death post radiation (Maguire et al., 2005; O'Reilly and Mothersill, 1997). Recently however, it has also been proposed as a method to determine the cell survival following exposure to other classes of xenobiotics (Franken et al., 2006; Glaviano et al., 2006).

Pulmonary and dermal exposures present the two main routes when handling nanomaterials (Donaldson et al., 2006; Maynard et al., 2004). Both lung and dermal cell lines were therefore chosen as test models for this in vitro study to assess and compare the long-term toxicity of two types of raw SWCNT samples and nanosized carbon black.

\section{Materials and methods}

\subsection{Test materials}

HiPco ${ }^{\circledR}$ derived SWCNT were purchased from Carbon Nanotechnologies, Inc. (Houston, TX). This material contained $10 \mathrm{wt} \%$ iron catalyst residuals. Atomic force microscopy (AFM) revealed $\mathrm{HiPco}^{\circledR}$ SWCNT in their as produced state to be on average $800 \mathrm{~nm}$ long. The diameter distribution of these $\mathrm{HiPco}^{\circledR}$ tubes was previously determined to be $0.8-1.2 \mathrm{~nm}$ by Raman spectroscopy conducted in our laboratory (Hedderman, 2006). Arc discharge synthesized SWCNT were obtained from Sigma-Aldrich, product number 519308 (Dublin, Ireland) containing 50-70\% SWCNT and trace amounts $(<1 \mathrm{wt} \%)$ of nickel and yttrium catalysts, the dominant impurity being amorphous carbon and turbostratic graphite. Arc discharge tubes range from $1.2 \mathrm{~nm}$ to $1.5 \mathrm{~nm}$ in diameter and $2-5 \mu \mathrm{m}$ in length, occurring in bundles of around $20 \mu \mathrm{m}$ length (Hedderman, 2006). AFM showed estimated bundle sizes of $2.6 \times 10^{-14} \mathrm{~m}^{2}$ and $4.1 \times 10^{-14} \mathrm{~m}^{2}$ for HiPco ${ }^{\circledR} \mathrm{SWCNT}$ and arc discharge SWCNT samples, respectively. Carbon black (CB) particles were kindly provided by Degussa AG (Frankfurt am Main, Germany) and had a mean diameter of $14 \mathrm{~nm}$.

\subsection{Cell culture}

A549 cells (ATCC, CCL-185), a human lung carcinoma epithelial cell line, BEAS-2B (ECACC, 95102433) normal human bronchial epithelial cells and $\mathrm{HaCaT}$ cells, normal human keratinocytes (kindly provided by Prof. Dr. Boukamp, Heidelberg), were all grown in Dubeccos's modified minimum essential medium (DMEM, Cambrex). All media were supplemented with $10 \%$ foetal bovine serum (FBS) and $45 \mathrm{IU} / \mathrm{ml}$ penicillin and $45 \mu \mathrm{g} / \mathrm{ml}$ streptomycin and cells were maintained at $37^{\circ} \mathrm{C}$ in a $5 \% \mathrm{CO}_{2}$ humidified incubator. 


\subsection{Dispersion of nanomaterials}

An ultrasonic tip (Ultra sonic processor VCX-750 W) operating at $40 \%$ for a total time of $30 \mathrm{~s}$ carried out in $10 \mathrm{~s}$ sequential steps was employed to disperse the nanoparticle solutions prior to preparation of test concentrations. TEM studies in our laboratories on samples prepared in an identical fashion have indicated that the SWCNT remain bundled after dispersion (Casey et al., 2007b). Cells were then exposed to a concentration range of $0-400 \mu \mathrm{g} / \mathrm{ml}$ of SWCNT and carbon black.

\subsection{Clonogenic assay}

The procedure for the clonogenic assay was adopted from Puck and Markus (1956) and Franken et al. (2006) and cells were treated after plating. Exponentially growing cells were harvested and seeded in six-well microplates (Nunc, Denmark) at a density of 250 cells/well for A549 cells and 300 cells/well for HaCaT and BEAS-2B cells. Each well contained $2 \mathrm{ml}$ of cell culture medium. Cells were allowed to attach for approximately $14 \mathrm{~h}$. This attachment period was shorter than the population doubling time of these cell lines which is reported to be around $22 \mathrm{~h}$ for A549 cells (ATCC, CCL-185), $23 \mathrm{~h}$ for HaCaT (Boukamp et al., 1988) and $27 \mathrm{~h}$ for BEAS-2B cells (Reddel, personal communication, 7 Aug 2007). Therefore, it can be assumed that mostly single cells were present at the time of exposure. Cells were then washed with $2 \mathrm{ml}$ of phosphate buffered saline (PBS) and treated with $2 \mathrm{ml}$ of nanoparticles prepared in cell culture medium to final concentrations of $0 \mu \mathrm{g} / \mathrm{ml}, 1.56 \mu \mathrm{g} / \mathrm{ml}, 25 \mu \mathrm{g} / \mathrm{ml}, 100 \mu \mathrm{g} / \mathrm{ml}$ and $400 \mu \mathrm{g} / \mathrm{ml}$. In other terms, cells were exposed to $0 \mu \mathrm{g}, 0.32 \mu \mathrm{g}$, $1.30 \mu \mathrm{g}, 5.20 \mu \mathrm{g}, 20.79 \mu \mathrm{g}$ and $83.16 \mu \mathrm{g}$ of nanoparticles per $\mathrm{cm}^{2}$ of cell monolayer. Exposure concentrations were chosen to be comparable to previous studies investigating the toxicity of carbon nanotube material (Jia et al., 2005; Pulskamp et al., 2007; Kagan et al., 2006; Tian et al., 2006; MonteiroRiviere et al., 2005; Shvedova et al., 2003). Carbon particles in solution behave very differently to molecules and following sonication, the main particle fraction tends to settle onto the bottom of the culture vessels. Therefore, it was decided to express the exposure doses as mass of particles per exposed surface area $\left(\mu \mathrm{g} / \mathrm{cm}^{2}\right)$ in addition to mass per volume $(\mu \mathrm{g} / \mathrm{ml})$. However, due to the wide length distribution of nanotube samples and varying surface areas depending on the degree of aggregation, exact characterization of exposure doses was still difficult (Jia et al., 2005). Expressing the concentration as particle number per cell was not applicable to this study as single cell or cell colonies are exposed to particles during the clonogenic assay rather than a uniform cell monolayer. Therefore, the majority of particles will settle to the bottom of the culture vessel and will not get into direct contact with the cells.

Cells were exposed to nanoparticles over the time period they needed to form colonies, a colony being defined as at least 50 clones of one cell. Both A549 and BEAS-2B cells were incubated for 10 days, whereas HaCaT cells had formed suffi- ciently large colonies after only 7 days. Therefore, cells were exposed to nanoparticles for 10 or 7 days, respectively. Before colonies were counted, particle solutions were removed, cells were washed with PBS and finally fixed and stained using a $20 \%$ carbol fuchsin in formalin solution (BDH, Poole, UK). The average plating efficiencies of cells were $74.8 \%$ for A549 cells, $39.8 \%$ for $\mathrm{HaCaT}$ and $32.0 \%$ for BEAS-2B cells. In addition to colony number as the classical clonogenic assay endpoint, surface area was chosen as an additional endpoint to evaluate the effects of nanoparticles on colony formation (Spadinger et al., 1994). Digital photographs were taken from each six-well microplate and the Java based image processing program ImageJ (http://rsb.info.nih.gov/ij/) was used to measure colony surface areas.

\subsection{Statistics}

At least three independent experiments were conducted for each cell line and type of nanoparticle. Test results for each assay were expressed as percentage of the unexposed control \pm standard deviation (S.D.). Control values were set as $100 \%$. Differences between samples and the control were evaluated using the statistical analysis package SPSS 14.0. Statistical significant differences were set at $P \leq 0.05$. Normality of data was confirmed with $\mathrm{Q}-\mathrm{Q}$ percentile plots and Kolmogorov-Smirnov tests. Equality of variances was evaluated using Levène tests. One-way analysis of variances (ANOVA) followed by Dunnett's multiple comparison tests were carried out for normally distributed samples with homogeneous variances. Non-parametric tests, namely Kruskal-Wallis followed by Mann-Whitney- $U$-tests were applied to samples without normal distribution and/or inhomogeneous variances.

Cytotoxicity data was fitted to a normal log or exponential growth model in order to calculate the $50 \%$ effective concentration $\left(\mathrm{EC}_{50}\right)$ values, the particle concentration that causes an estimated $50 \%$ effect in comparison to untreated controls. This analysis was performed using REGTOX-EV6.xls (Èric Vindimian, http://eric.vindimian.9online.fr/) and were confirmed using Xlfit $3^{\mathrm{TM}}$ (ID Business Solutions, UK), both curve fitting add-ins for Microsoft ${ }^{\circledR}$ Excel. EC $_{50}$ values are reported \pm S.D.

\section{Results and discussion}

\subsection{Pulmonary toxicity of carbon nanomaterials}

The lung is a common target of many toxicants due to its large surface area. When inhaled, particles reach the alveolar epithelial surface where they can interact with alveolar macrophages and epithelial cells (Driscoll, 1995). Therefore, A549 human lung epithelial carcinoma and BEAS-2B normal human bronchial epithelium were chosen to assess the effects of inhalation exposure to nanoparticles. 

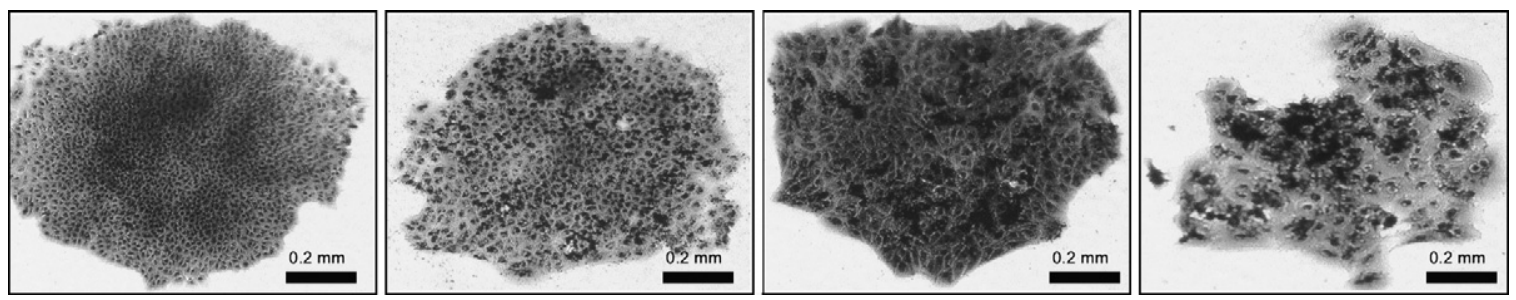

Fig. 1. Colonies of A549 cells after 10-day exposure to $400 \mu \mathrm{g} / \mathrm{ml}$ of carbon nanomaterials $\times 20$ magnification (left to right: control, Printex 90 , ArcD SWCNT, HiPco ${ }^{\circledR}$ SWCNT exposed colonies).

The toxicity of inhaled particles is determined by their biopersistence. Fibres and particles remaining in the lung are more likely to cause fibrosis and/or cancer compared to particles that are rapidly cleared (Donaldson et al., 2006; Oberdörster et al., 2005). As demonstrated in Fig. 1 for A549 cells, after prolonged exposure to carbon nanomaterials, aggregates of particles tend to selectively adhere to the cell colonies rather than the substrate. This was the same for all cell lines tested. Several consecutive washing steps with PBS and water were not able to remove these aggregates from the cell surfaces. Aggregates of SWCNT seemed to be consistently larger compared to those formed by CB nanoparticles. It is this persistence of the carbon nanomaterials which can potentially cause interferences with colorometric assays. Active anchoring of nanotube bundles to exposed cells has also been reported by other authors and is thought to play a role in the formation of granuloma in animals exposed to SWCNT (Wörle-Knirsch et al., 2006). It should be noted that although some authors have reported internalization of SWNT and MWNT in cells other than macrophages (Monteiro-Riviere et al., 2005; Wörle-Knirsch et al., 2006), under the preparation conditions employed here, no internalization of nanotubes was observed (Davoren et al., 2007), and an indirect toxic mechanism, due to interaction of the nanotubes with the
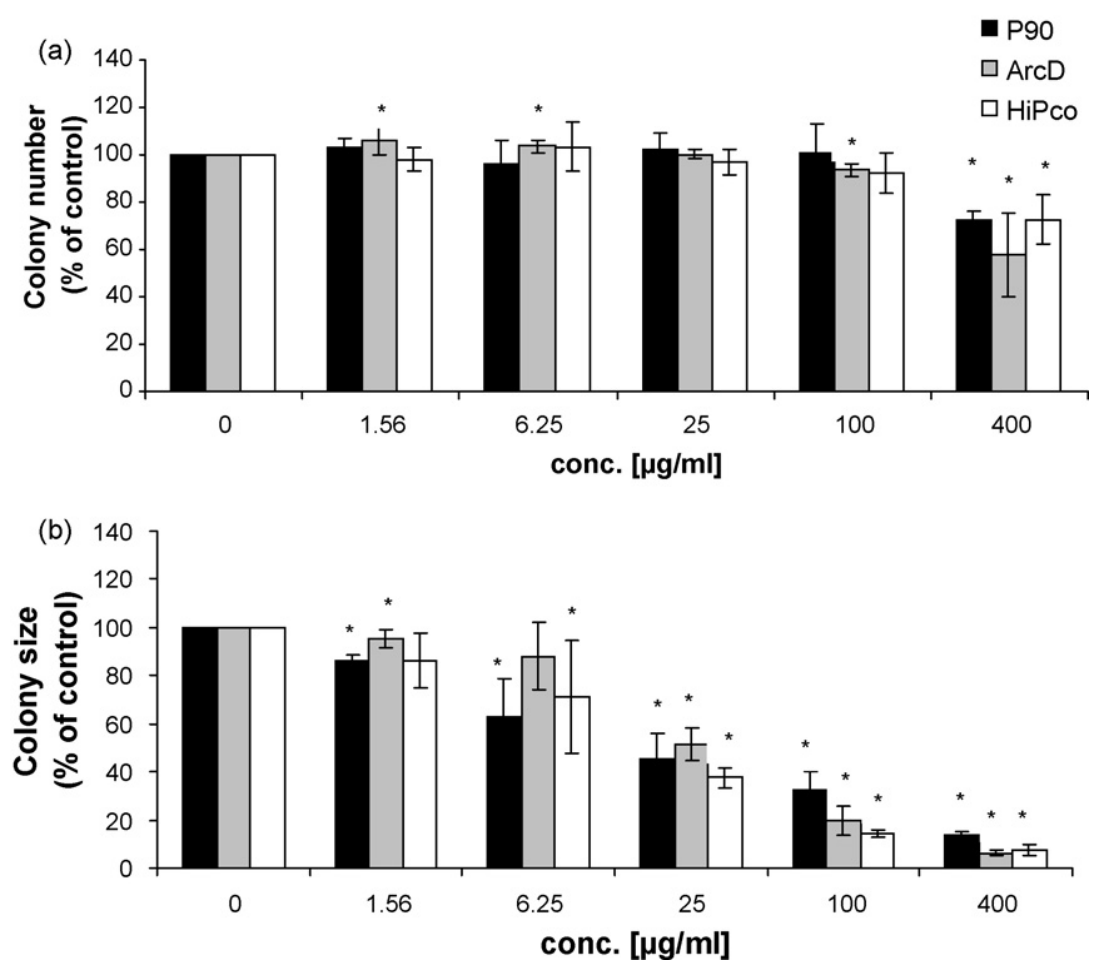

Fig. 2. Effects of carbon nanoparticle exposure on colony formation (a, effects on colony number; b, effects on colony size) of A549 cells. Bars showing colony numbers/size as determined following 10 days exposures to Printex 90 (black), arc discharge SWCNT (grey) and HiPco ${ }^{\circledR}$ SWCNT (white). Results are expressed as percent of control mean \pm S.D. of three independent experiments each carried out in triplicate. Asterisk $(*)$ denotes a significant difference from the control $(P \geq 0.05)$. 
cell culture medium has been suggested (Casey et al., 2007a). This is discussed further in Section 3.4.

As shown in Fig. 2a, after a 10-day exposure of A549 cells to carbon nanomaterials, colony numbers were reduced to around $72.0 \%, 57.7 \%$ and $72.6 \%$ for carbon black, arc discharge and HiPco ${ }^{\circledR}$ produced SWCNT compared to control, respectively. HiPco ${ }^{\circledR}$ SWCNT and carbon black could only elicit a statistically significant $(P \leq 0.05)$ reduction in colony number at the highest concentration tested. This confirms the results from previous studies showing ultrastructural changes and toxicity in A549 cells exposed to HiPco ${ }^{\circledR}$ SWCNT at concentrations of $400 \mu \mathrm{g} / \mathrm{ml}$ and $800 \mu \mathrm{g} / \mathrm{ml}$ as seen by TEM (Davoren et al., 2007). Arc discharge produced SWCNT caused a significant increase in the number of colonies of ca. $5.8 \%$ and $3.5 \%$ after exposure to $1.56 \mu \mathrm{g} / \mathrm{ml}$ and $6.25 \mu \mathrm{g} / \mathrm{ml}$. From $100 \mu \mathrm{g} / \mathrm{ml}$ on, a significant reduction could be determined.

In contrast to the relatively small effects identified on colony numbers of A549 cells, a greater effect was observed when looking at colony surface areas. Cells seemed to form much smaller colonies when exposed to carbon nanoparticles, also demonstrated in Fig. 3. These reductions in colony sizes were due to fewer cells being present within the exposed colonies whereas individual cell sizes remained unchanged.

It is clear that although the colony number is not dramatically affected by the exposure to the nanoparticles, their capacity to grow and proliferate is significantly reduced. It is therefore proposed that colony size is a valid endpoint to monitor the effect of the nanoparticles.

Using colony size as an additional endpoint for toxicity assessment, significant effects could be observed for all particles at concentrations as low as $25 \mu \mathrm{g} / \mathrm{ml}$
(Fig. 2b). Size reduction after carbon black and arc discharge SWCNT exposure were even significant at concentrations of $1.56 \mu \mathrm{g} / \mathrm{ml}$, HiPco ${ }^{\circledR}$ SWCNT from concentrations of $6.25 \mu \mathrm{g} / \mathrm{ml}$ on. A dose-dependent reduction in colony size could be determined for all three particle types tested with size inhibitions down to only $13.6 \%, 6.2 \%$ and $7.5 \%$ compared to control for carbon black, arc discharge and HiPco ${ }^{\circledR}$ produced SWCNT, respectively.

Considering both endpoints, colony number and size, it could be concluded that all types of carbon nanomaterials tested were able to significantly decrease clonogenic survival and cell proliferation in a dose-dependent fashion when exposed constantly over 10 days. As illustrated in Fig. 2, colony surface area measurements seemed to be significantly more sensitive as an endpoint compared to the classically performed colony number counts when assessing the effects of all three types of carbon nanoparticles on A549 lung cells.

To be able to compare and rank the toxicity of the particles tested, $\mathrm{EC}_{50}$ values were calculated for both the effects on colony numbers and colony sizes, as shown in Table 1. $\mathrm{EC}_{50}$ s of A549 cells in terms of colony number were determined to be greater than the highest concentration of $400 \mu \mathrm{g} / \mathrm{ml}$ for all particles tested. However, the $\mathrm{EC}_{50} \mathrm{~s}$ in terms of colony size were all considerably less, ranging between $15 \mu \mathrm{g} / \mathrm{ml}$ and $28 \mu \mathrm{g} / \mathrm{ml}$ with $\mathrm{HiPco}^{\circledR}$ SWCNT being most toxic.

Transformed cell lines such as A549 cells are frequently referred to as being more resistant to toxic insults compared to cells derived from normal tissue, possibly due to higher glutathione and catalase antioxidant activities (Järvinen et al., 2000; Russo et al., 1986). Therefore, in addition to the A549 cell line, the clonogenic assay
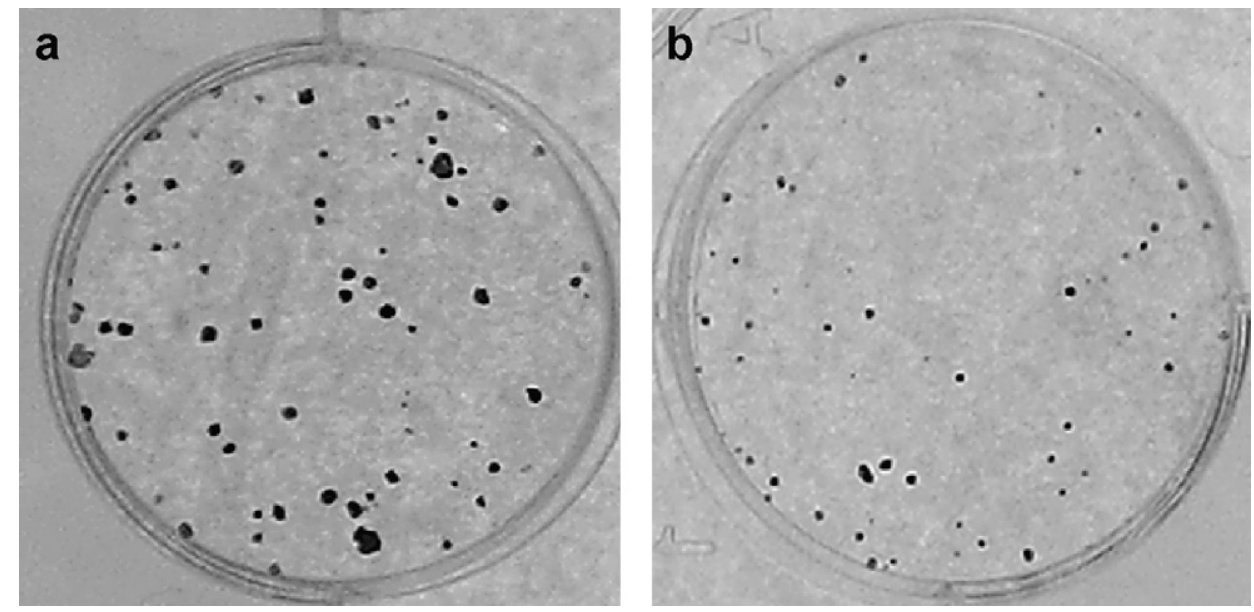

Fig. 3. Colonies of A549 cells after 10 days incubation with (a) DMEM cell culture medium only and (b) $400 \mu \mathrm{g} / \mathrm{ml}$ HiPco ${ }^{\circledR}$ SWCNT dispersed in DMEM cell culture medium. 
Table 1a

$\mathrm{EC}_{50}[\mu \mathrm{g} / \mathrm{ml}]$ values for inhibition of colony number of A549, BEAS$2 \mathrm{~B}$ and $\mathrm{HaCaT}$ cell lines following exposure to Printex 90 carbon black, arc discharge SWCNT and HiPco ${ }^{\circledR}$ SWCNT

\begin{tabular}{lrrr}
\hline & Carbon black & \multicolumn{1}{l}{$\begin{array}{l}\text { Arc discharge } \\
\text { SWCNT }\end{array}$} & \multicolumn{1}{c}{ HiPco $^{\circledR}$ SWCNT } \\
\hline A549 & $>400 \pm 0.41$ & $>400 \pm 1.05$ & $>400 \pm 1.79$ \\
BEAS-2B & $14.66 \pm 1.74$ & $13.70 \pm 1.95$ & $4.39 \pm 0.99$ \\
HaCaT & $180.90 \pm 0.68$ & $106.23 \pm 2.18$ & $40.29 \pm 2.42$ \\
\hline
\end{tabular}

Results are $\mathrm{EC}_{50}$ values \pm S.D.

Table $1 \mathrm{~b}$

$\mathrm{EC}_{50}[\mu \mathrm{g} / \mathrm{ml}]$ values for inhibition of colony size of A549 and $\mathrm{HaCaT}$ cell lines following exposure to Printex 90 carbon black, arc discharge SWCNT and $\mathrm{HiPco}^{\circledR}$ SWCNT

\begin{tabular}{llll}
\hline & Carbon black & $\begin{array}{l}\text { Arc discharge } \\
\text { SWCNT }\end{array}$ & HiPco $^{\circledR}$ SWCNT \\
\hline A549 & $20.63 \pm 2.81$ & $28.38 \pm 1.47$ & $15.04 \pm 1.89$ \\
HaCaT & $78.78 \pm 1.53$ & $27.35 \pm 2.20$ & $23.38 \pm 1.81$ \\
\hline
\end{tabular}

Results are $\mathrm{EC}_{50}$ values \pm S.D.

was also carried out on the normal bronchial epithelial cell line BEAS-2B.

As illustrated in Fig. 4, exposure of BEAS-2B cells to carbon nanomaterials over 10 days resulted in a dose-dependent reduction in colony number, being statistically significant at all concentrations tested. At the highest concentration, BEAS-2B cells were no longer able to form colonies, indicating a high degree of cell toxicity. Unfortunately, no colony surface area measurements were possible for this cell line due to the high motility of cells resulting in widely spread colonies. Comparing $\mathrm{EC}_{50}$ values on the effects of nanoparticle

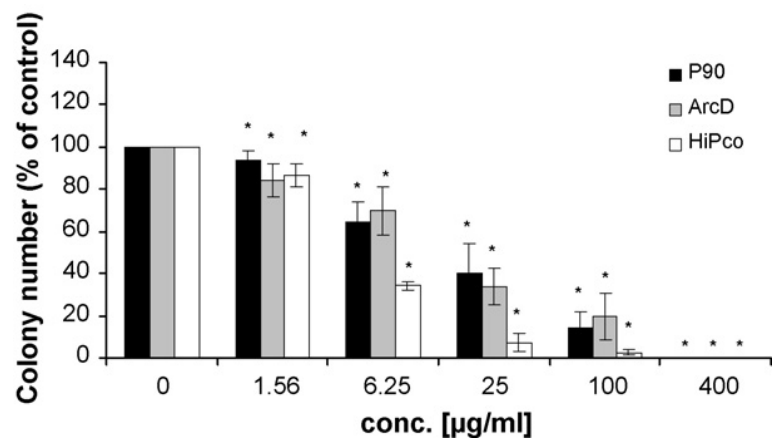

Fig. 4. Effects of carbon nanoparticle exposure on colony formation of BEAS-2B cells. Bars showing colony numbers as determined following 10 days exposures to Printex 90 (black), arc discharge SWCNT (grey) and HiPco ${ }^{\circledR}$ SWCNT (white). Results are expressed as percent of control mean \pm S.D. of three independent experiments each carried out in triplicate. Asterisk $(*)$ denotes a significant difference from the control $(P \geq 0.05)$. exposure on colony numbers, $\mathrm{HiPco}^{\circledR}$ SWCNT appeared to be more than three times as toxic to BEAS-2B cells compared to arc discharge SWCNT and carbon black (Table 1a). Compared to A549 lung carcinoma cells, the normal lung cell line seemed to be significantly more sensitive to nanoparticle exposures. It should be noted that BEAS-2B cells were grown in DMEM growth medium in contrast to the recommended LHC- 8 culture medium. Due to interactions observed between culture medium components and SWCNT, using the same type of culture medium for all three cell lines made it possible to compare the effects of SWCNT on these three cell lines. However, the use of DMEM rather than LHC-8 may influence the characteristics of BEAS-2B cells.

\subsection{Dermal toxicity of carbon nanomaterial}

The skin with its large surface area is another potential route for occupational and environmental exposure to nanomaterials and serves as one of the principal portals of entry for nanoparticles (Monteiro-Riviere and Inman, 2006). Dermal keratinocytes play an important role in the cell renewal system and in maintaining skin integrity and are commonly used as a model for testing dermal toxicity (Shvedova et al., 2003; Van de Sandt et al., 1999) Therefore, the immortalized non-tumorigenic human dermal keratinocyte cell line $\mathrm{HaCaT}$ was chosen as the in vitro model for dermal exposure.

$\mathrm{HaCaT}$ cells formed colonies after only 7 days of incubation compared to the 10 days needed for the lung cells tested. Therefore, cells were constantly exposed to carbon nanomaterials for 7 days and results are shown in Fig. 5. All three types of carbon particles exhibited dose-dependent effects on the clonogenic survival of $\mathrm{HaCaT}$ cells. At concentrations of $400 \mu \mathrm{g} / \mathrm{ml}$, colony numbers were reduced by $89 \%, 86 \%$ and $85 \%$ following carbon black, arc discharge and $\mathrm{HiPco}^{\circledR}$ SWCNT exposures, respectively. Furthermore, colony size was demonstrated to decrease by more than $80 \%$ compared to control colonies following exposure to all three types of particles at this concentration. For all three particles tested, significant reductions in colony number and size could be observed at concentrations starting at $25 \mu \mathrm{g} / \mathrm{ml}$. SWCNT were able to significantly decrease colony sizes at concentrations as low as $6.25 \mu \mathrm{g} / \mathrm{ml}$.

Comparing $\mathrm{EC}_{50} \mathrm{~s}$ for the clonogenic survival of HaCaT cells, as shown in Table 1, it can be concluded that SWCNT are significantly more toxic compared to carbon black. In terms of colony number, HiPco ${ }^{\circledR}$ SWCNT appeared more than twice as toxic as arc discharge produced SWCNT. However, only a small difference 

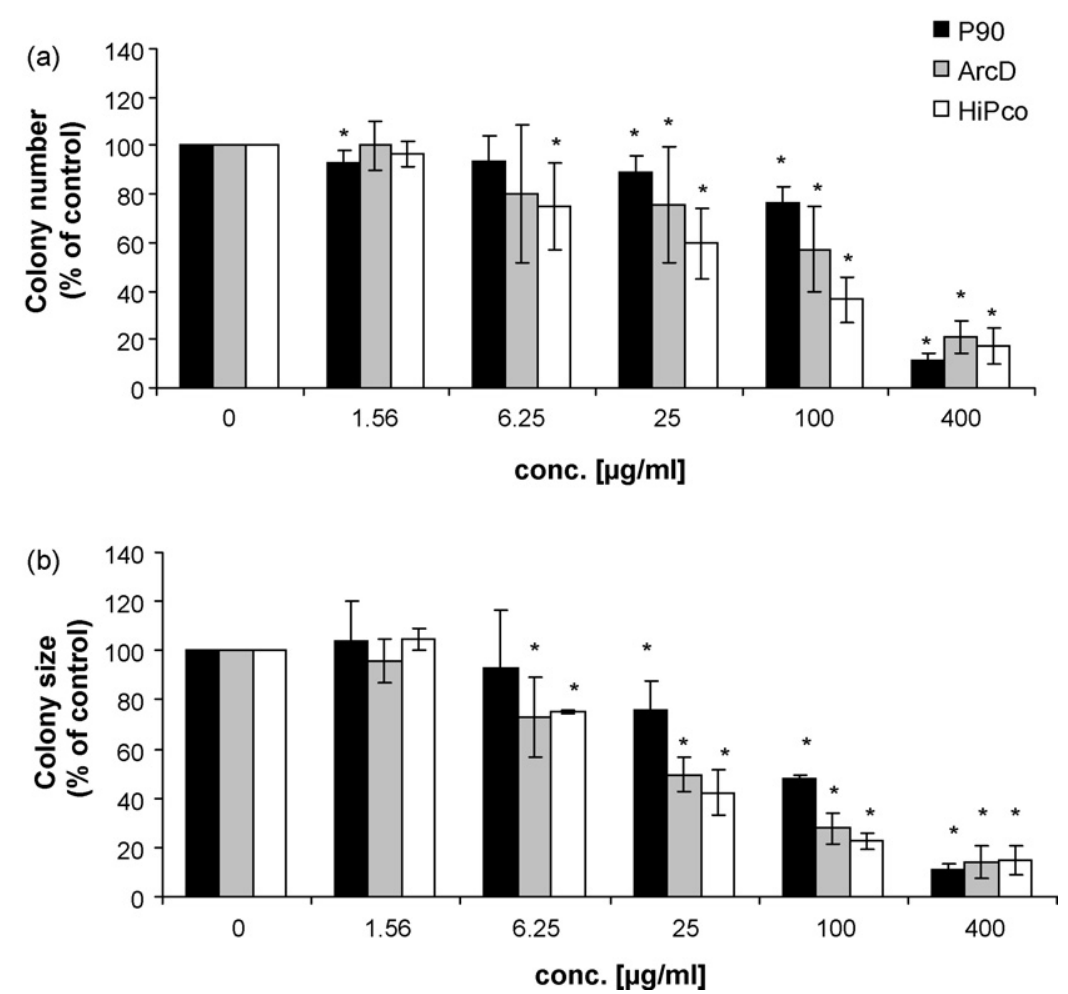

Fig. 5. Effects of carbon nanoparticle exposure on colony formation (a, effects on colony number; b, effects on colony size) of HaCaT cells. Bars showing colony numbers as determined following 7 days exposures to Printex 90 (black), arc discharge SWCNT (grey) and HiPco ${ }^{\circledR}$ SWCNT (white). Results are expressed as percent of control mean \pm S.D. of three independent experiments each carried out in triplicate. Asterisk $(*)$ denotes a significant difference from the control $(P \geq 0.05)$.

between the toxicity of the two types of SWCNT was noted in terms of colony size.

Both the colony number and colony surface area endpoints, as illustrated in Fig. 5 appear to correlate very well for $\mathrm{HaCaT}$ cells. Colony surface area appeared to be slightly more sensitive and more reproducible, resulting in smaller data variability. In contrast, for A549 cells, surface area measurements and colony number differed greatly. This might indicate increased cell death of $\mathrm{HaCaT}$ cells following exposure to carbon nanomaterials whereas A549 cells appeared more resistant, still forming colonies at very high concentrations, only responding with decreased cell proliferation.

\subsection{Particle toxicity comparison}

To our knowledge this is the first study employing the clonogenic assay to determine the toxicity of engineered nanoparticles. To date, toxicity studies are based on mostly non-standardized CNT material making it complicated to perform comparisons between studies (Wörle-Knirsch et al., 2006). Overall, the findings on the cytotoxicity of carbon nanomaterials appear to be contradictory. Discrepancies between studies may be explained by differences in sample preparation, sample composition and/or assay system used. There are only limited studies available imitating the occupational exposure situation to carbon nanomaterials by not using any surfactants, functionalization of SWCNT or acid treatment.

This study compares as produced commercial carbon nanotube samples, and the toxic response is to the sample in its entirety, including impurities. The potential role of impurities is discussed further in Section 3.3.2, but it should be noted that with current state of the art production methods, occupational exposure and therefore potential toxicity is to the sample in its entirety.

Results of the clonogenic assay suggest that both SWCNT samples produced by HiPco ${ }^{\circledR}$ and arc discharge as well as nanosized carbon black exhibit cytotoxicity and reduce cell proliferation in a dose-dependent fashion in all three cell lines tested. The lowest $\mathrm{EC}_{50}$ values, as illustrated in Table 1, were determined for HiPco ${ }^{\circledR}$ SWCNT exposures for all three cell lines and both endpoints, colony number and colony size. This indicates HiPco ${ }^{\circledR}$ SWCNT to be the most cytotoxic of the parti- 
cles tested. Pulskamp et al. (2007) also exposed A549 cells to SWCNT for 24-96h and concluded no acute toxicity, indicating the importance of long-term studies for the identification of SWCNT toxicity. Carbon black appeared to be less toxic in our study compared to the two types of SWCNT.

\subsubsection{SWCNT versus carbon black}

Carbon black nanoparticles were effective in reducing clonogenic survival but to a lesser extent compared to the two types of SWCNT. As arc discharge SWCNT do not contain iron residues or significant amounts of other transition metals, this may indicate that nanotube material is intrinsically more bioreactive compared to amorphous carbon nanoparticles such as carbon black. In contrast, carbon black particles seemed more toxic compared to MWCNT to lung tumour cells following exposure for $24 \mathrm{~h}$ up to 5 days in a study by Magrez et al. (2006). The high toxicity of carbon black was suspected to be due to the presence of highly reactive dangling bonds present at a high density in carbon black but only present at lattice defects and end caps of carbon nanotubes. Higher toxicity of carbon black compared to SWCNT was also reported by other authors (Pulskamp et al., 2007). However, dye-based assays were employed for cytotoxicity assessment in these studies, making interpretation difficult. In our study, carbon black particles had a very similar effect to SWCNT when assessing colony size but were much less toxic when assessing colony number as endpoint.

Murr et al. (2005) reported cytotoxic responses of murine lung macrophages to carbon nanotube aggregates to be essentially identical to nanoparticle carbon black aggregates as well as chrysotile asbestos fibril aggregates. Authors concluded that it is unlikely that cytotoxicities are morphologically specific. This would correlate well with the effects on A549 cells seen in this study, where no significant difference between the effects of the three types of carbon nanoparticles could be determined. However, treatment of HaCaT and BEAS2B cells did show differences in particle toxicities. Also Jia et al. (2005) concluded that nanomaterials with different geometric structures exhibit different cytotoxicities and bioactivities in vitro following comparisons between SWCNT, MWCNT and fullerenes.

\subsubsection{Arc discharge SWCNT versus HiPco ${ }^{\circledR}$ SWCNT samples}

To the best of our knowledge, no studies have been published to date that directly compare the toxic effects of SWCNT produced by the HiPco ${ }^{\circledR}$ and arc discharge method. In this study, arc discharge and HiPco ${ }^{\circledR}$ SWCNT seemed to exhibit different effects on colony numbers and therefore clonogenic survival of $\mathrm{HaCaT}$ and BEAS-2B cells. These discrepancies may be due to differences in metal catalyst residue type and metal and carbon residue content of the samples. The microstructure of SWCNT consists of bundles of SWCNT which are aggregated with residual catalyst nanoparticles or other nanoparticle contamination, particularly graphite residues. The HiPco ${ }^{\circledR}$ SWCNT sample tested contained $10 \mathrm{wt} \%$ iron residues whereas arc discharge SWCNT contained a high amount of amorphous carbon impurities and very small residues of nickel and yttrium. Transition metal components of ultrafine particles (PM10), such as iron, are highly oxidative and reactive in biological systems and have been demonstrated to cause deleterious effects (Gilmour et al., 1997). There is strong evidence that they are able to stimulate proinflammatory responses in vivo and in vitro and have been postulated to play an important role in the toxicity of $\mathrm{HiPco}^{\circledR}$ SWCNT (Dreher, 2004; Kagan et al., 2006). The toxicity of catalytic metals may hide the real toxic effects of CNT (Tian et al., 2006) or may interact in a positive manner to generate inflammation (Wilson et al., 2002). This might explain the higher toxicity of $\mathrm{HiPco}{ }^{\circledR}$ SWCNT compared to arc discharge or carbon black as seen in this study. In contrast, Tian et al. (2006) reported refined SWCNT to be more cytotoxic to human dermal fibroblasts compared to unrefined SWCNT, active carbon, carbon black, MWCNT and carbon graphite.

Due to their geometry and hydrophobic surface, CNT have a tendency to form agglomerates with bundlelike form. Extensive efforts have been made to disperse CNT in organic solvents, surfactants and/or ultrasonication (Moore et al., 2003). However, extensive use of surfactants, organic solvents or functionalization leads to CNT material that cannot be considered representative for occupational exposure assessments (Wick et al., 2007). In this study, no surfactant was used in order to aid the dispersion of nanoparticles in cell culture medium so that the real exposure situation was mimicked as closely as possible. Raman and fluorescence emission analysis indicated no debundling or reduction in aggregation state upon dispersion of $\mathrm{HiPco}{ }^{\circledR} \mathrm{SWCNT}$ in the media over the concentration range studied (Casey et al., 2007b). However, bundle sizes of arc discharge and $\mathrm{HiPco}^{\circledR}$ SWCNT as present in organic media are different with an average of ca. $4.1 \times 10^{-14} \mathrm{~m}^{2}$ for arc discharge SWCNT and only about $2.6 \times 10^{-14} \mathrm{~m}^{2}$ for $\mathrm{HiPco}^{\circledR}$ produced SWCNT. The smaller bundle size of $\mathrm{HiPco}^{\circledR}$ SWCNT may therefore be an alternative explanation for their increased effect on cell viability. 
Differences in colony number, relatable to cell viability, after exposure to the different SWCNT samples may be ascribed to either different impurity content or bundle size. The colony size measurements did not reveal substantial differences between the two types of carbon nanotubes. This might point to a common toxicity mechanism of SWCNT on the rate of cell division and proliferation. The differences in catalyst residues and sample impurity content do not seem to play a role in this mechanism pointing towards a dependence of this effect on intrinsic SWCNT properties, as fundamentally the chemical composite of the nanotubes is the same.

\subsection{Interaction with cell culture media}

Ultrafine carbon black as well as SWCNT are known to interact and bind to a variety of organic molecules including sugars, proteins and cytokines (Casey et al., 2005; Hedderman et al., 2004; Monteiro-Riviere and Inman, 2006). Previous studies have also shown interaction between $\mathrm{HiPco}^{\circledR}$ SWCNT and the components of cell culture media (Casey et al., 2007b). This adsorptive nature of carbon-based nanomaterials may potentially lead to indirect, secondary toxicity by depleting cell growth media due to the binding of essential nutrients and/or cytokines and growth factors to particle surfaces. This nutrient depletion as a result of carbon particle exposure may affect cell viability and therefore colony formation, but more particularly colony sizes. It is well known that cells in nutrient deficient environment respond by reduced cell proliferation, ultimately leading to reduced colony sizes (Ozturk et al., 2003; Zenin et al., 1982). The fact that catalyst residues did not seem to significantly affect SWCNT toxicities, as indicated by similar $\mathrm{EC}_{50}$ values calculated by colony size, may also point to the conclusion that the effects of SWCNT on cell growth and proliferation may be a result of such an indirect toxicity.

This secondary toxicity must also be kept in mind when undertaking comparison studies as different types of cell culture media may be more prone to SWCNT interactions than others. In this study, all three cell lines tested were maintained and exposed using the same type of culture medium. Therefore, differences in cell line toxicity due to variations between growth media components can be discounted. However, carbon nanoparticles may have tendencies to selectively bind certain types of cytokines or growth factors which might differ between the three cell lines tested.

The effects of culture medium that has previously been exposed to carbon nanoparticles as well as the role of growth media type in SWCNT toxicity are currently under investigation.

\subsection{Cell line comparison}

We have shown that sensitivity to carbon nanomaterial differs between cell lines. Comparing $\mathrm{EC}_{50} \mathrm{~S}$ (Table 1), the human carcinoma lung cell line A549 was found to be much more resistant compared to the two normal human cell lines tested when assessing effects on colony number. None of the particles tested was able to exhibit $50 \%$ reduction in colony numbers of these cells. In contrast the normal lung cells BEAS-2B were the most sensitive, followed by HaCaT cells. Based on colony size, in contrast, A549 cells appeared more sensitive than HaCaT cells when exposed to carbon black, whereas SWCNT exposures had nearly the same effect on colony sizes for both cell lines, leading to maximum reductions of $85-93 \%$ compared to control colonies.

As illustrated for the example of HiPco ${ }^{\circledR}$ SWCNT exposures in Fig. 6, great discrepancies exist between the responses in colony number and colony size for
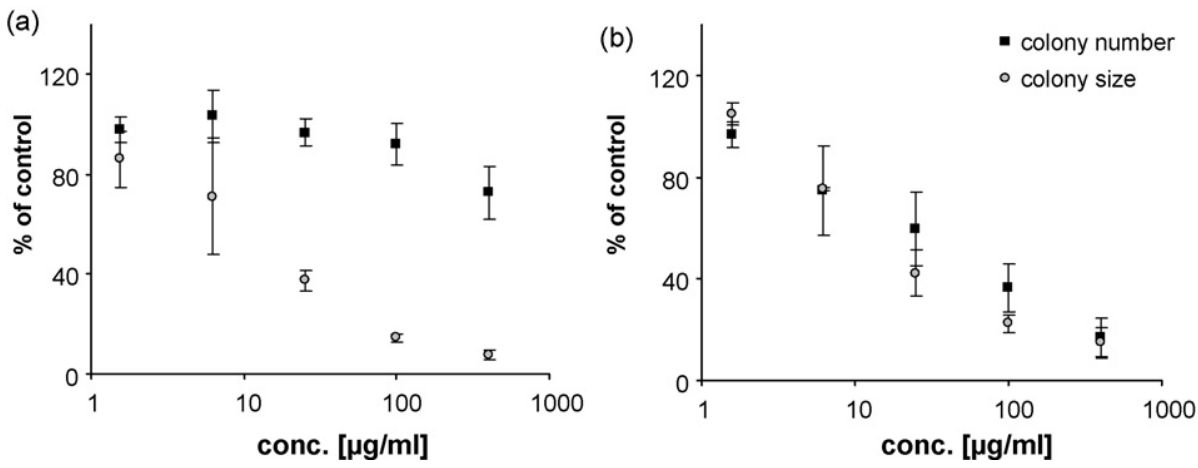

Fig. 6. Effects of HiPco ${ }^{\circledR}$ SWCNT exposure on colony number (black) vs. colony size (grey) of (a) A549 cells and (b) HaCaT cells. Results are expressed as percent of control mean \pm S.D. of three independent experiments each carried out in triplicate. 
A549 cells, whereas both endpoints correlate well for $\mathrm{HaCaT}$ cells. This was true for all three types of carbon nanoparticles tested. The ability of cells to form colonies has been widely used to screen xenobiotics for potential toxic activity (Franken et al., 2006). Only mitotically viable cells are capable of producing clones and therefore colonies. As a result, the number of colonies formed after or during treatment indicates cell viability as these cells are able to stay attached to the culture vessel surface and are able to undergo a certain amount of cell divisions. Colony size is a more sensitive endpoint measuring the number of cells per colony which can be used to estimate the rate of division and proliferation of treated cells (Horáková et al., 2001).

Therefore, the results presented indicate that both cell lines respond similarly in decreasing cell proliferation but very differently regarding cell death. Due to the high rate of cell migration of BEAS-2B cells during exposure and colony formation, no accurate measurement of colony sizes could be carried out. However, it was noted that the number of cells per colony decreased with exposure to increased particle concentrations. It also appears that A549 cells' main response to carbon nanoparticle exposure is reduction of their rate of proliferation while maintaining their viability. HaCaT cells, in contrast, respond equally in loss of cell viability and decreased cell proliferation. Manna et al. (2005) also reported inhibition of cell proliferation upon treatment of $\mathrm{HaCaT}$ cells with SWCNT particles following $72 \mathrm{~h}$ exposure and reported similar findings using A549 cells suggesting a common toxicity mechanism. Yet, in their study, SWCNT were dissolved in dimethylformamide, making direct study comparisons difficult.

Including both colony number and colony size measurements in the clonogenic assay enables distinction between effects on general cell viability and cell proliferation, making it a highly useful tool in cytotoxicity testing. Furthermore, the clonogenic assay has been reported to be more sensitive than colorimetric proliferation assays which measure the numbers of viable cells. Colorimetric assays fail when synthesis of protein, DNA, RNA, lysosomal or mitochondrial enzymes is induced in an arrested cell population without any change in cell numbers (Horáková et al., 2001). Some cells that are scored as healthy by colorimetric methods may actually be injured and are to die at some later time (Perez et al., 1992). Therefore, the clonogenic assay offers the possibility of long-term toxicity assessment at a sub-lethal level. In addition, it does not involve any fluorescence or absorbance measurements as indicators for cell viability. Therefore, the clonogenic assay provides a more realistic and reliable estimate of the toxicity of carbon-based nanomaterials compared to colorimetric dye-based assays, as any interactions between carbon nanoparticles and indicator dyes can be avoided. A correlation study between standard colorimetric methods and the clonogenic assay in terms of nanoparticle toxicity is currently underway. In addition, the effects on cell proliferation could be elucidated by including quantification of DNA synthesis following particle exposures.

\section{Conclusion}

In this study, it was possible to show differences in cytotoxicity between two types of carbon nanomaterials, SWCNT and carbon black with nanotube material being intrinsically more reactive compared to amorphous carbon nanoparticles. Furthermore, it could be shown that the toxicity of SWCNT differs according to the production method used, with HiPco ${ }^{\circledR}$ SWCNT being more reactive compared to arc discharge produced SWCNT. The effects on colony numbers indicate that residual metal catalyst particles may contribute to the primary toxic response. In terms of proliferative capacity, however, the different types of SWCNT had similar effects, indicating a common possibly secondary mechanism which might be partly the result of the adsorptive interaction between SWCNT bundles and the molecular components of the medium.

Different cell lines manifest differing degrees of cytotoxic response in terms of cell viability and proliferation, highlighting increased sensitivity of normal cell lines in comparison to carcinoma cell lines and differences in tissue sensitivity.

Previous studies showed that SWCNT interact with colorimetric indicator dyes frequently used for toxicity screening, such as Neutral Red, MTT, WST-1 or Alamar blue, resulting in quenched fluorescence and/or absorbance. By employing the clonogenic assay as an alternative to these commonly used absorbance or fluorescence-based assays, any adsorptive interactions between nanomaterial and indicator dyes could be overcome, allowing a more realistic and accurate toxicity determination. Even though the use of the clonogenic assay as a high-throughput assay is limited, this assay offers the possibility for the in vitro assessment of longterm toxicity including sub-lethal endpoints, making it highly sensitive and valuable. In this study, it could be illustrated that including measurements of colony surface area as an additional endpoint makes the assay even more sensitive and allows distinction between effects on cell viability and cell proliferation as two separate endpoints. Therefore, we recommend the clonogenic assay 
for the toxicity evaluation of carbon-based nanomaterials on colony forming cell lines.

\section{Acknowledgements}

Eva Herzog is funded under the Technological Sector Research Strand I, Post Graduate R\&D Skills Programme.

\section{References}

Bianco, A., Kostarelos, K., Prato, M., 2005. Applications of carbon nanotubes in drug delivery. Curr. Opin. Chem. Biol. 9, 674679.

Boukamp, P., Petrussevska, R.T., Breitkreutz, D., Hornung, J., Markham, A., Fusenig, N.E., 1988. Normal keratinisation in a spontaneously immortalized aneuploid human keratinocyte cell line. J. Cell Biol. 106, 761-771.

Brown, J.M., Attardi, L.D., 2005. The role of apoptosis in cancer development and treatment response. Nat. Rev. Cancer 5, 231-237.

Casey, A., Farrell, G.F., McNamara, M., Byrne, H.J., Chambers, G., 2005. Interaction of carbon nanotubes with sugar complexes. Synth. Met. 153, 357-360.

Casey, A., Davoren, M., Herzog, E., Lyng, F.M., Byrne, H.J., Chambers, G., 2007b. Probing the interaction of single walled carbon nanotubes within cell culture medium as a precursor to toxicity testing. Carbon 45, 34-40.

Casey, A., Herzog, E., Davoren, M., Lyng, F.M., Byrne, H.J., Chambers, G., 2007a. Spectroscopic analysis confirms the interactions between single walled carbon nanotubes and various dyes commonly used to assess cytotoxicity. Carbon 45, 1425-1432.

Davoren, M., Herzog, E., Casey, A., Cottineau, B., Chambers, G., Byrne, H.J., Lyng, F.M., 2007. In vitro toxicity evaluation of single walled carbon nanotubes on human A549 lung cells. Toxicol. In Vitro 21, 438-448.

De Jonge, N., Bonard, J.M., 2004. Carbon nanotube electron sources and applications. Philos. Trans. Ser. A. Math. Phys. Eng. Sci. 362, 2239-2266.

Donaldson, K., Aitken, R., Tran, L., Stone, V., Duffin, R., Forrest, G., et al., 2006. Toxicology of carbon nanotubes. Toxicol. Sci. 92, 522.

Dreher, K.L., 2004. Health and environmental impact of nanotechnology: toxicological assessment of manufactured nanoparticles. Toxicol. Sci. 77, 3-5.

Driscoll, K.E., 1995. Role of cytokines in pulmonary inflammation and fibrosis. In: Mc Clellan, R.O., Henderson, R.F. (Eds.), Concept in Inhalation Toxicology. Taylor and Francis, London, pp. 471-496.

Franken, N.A.P., Rodermond, H.M., Stap, J., Haveman, J., van Bree, C., 2006. Clonogenic assay of cells in vitro. Nat. Protocols 1, 2315-2319.

Gilmour, P.S., Brown, D.M., Beswick, P.H., 1997. Free radical activity of industrial fibres: role of iron in oxidative stress and activation of transcription factors. Environ. Health Perspect. 105, 1313-1317.

Glaviano, A., Nayak, V., Cabuy, E., Baird, D.M., Yin, Z., Newson, R., Ladon, D., Rubio, M.A., Slijepcevic, P., Lyng, F., Mothersill, C., Case, C.P., 2006. Effects of hTERT on metal ion-induced genomic instability. Oncogene 25, 3424-3435.

Hedderman, T.G., Keogh, S.M., Chambers, G., Byrne, H.J., 2004. Solubilisation of single walled carbon nanotubes with organic dye molecules. J. Phys. Chem. B 108, 18860-18865.
Hedderman, T.G., 2006. Ph.D. Thesis. Dublin, pp. 91-103.

Horáková, K., Šovčíková, A., Seemannová, Z., Syrová, D., Bušányová, K., Drobná, Z., Ferenčík, M., 2001. Detection of drug-induced, superoxide-mediated cell damage and its prevention by antioxidants. Free Radic. Biol. Med. 30, 650-664.

Huczko, A., 2002. Synthesis of aligned carbon nanotubes. Appl. Phys., A Mater. Sci. Process. 74, 617-638.

Hurt, R.H., Monthioux, M., Kane, A., 2006. Toxicology of carbon nanomaterials: status, trends, and perspectives on the special issue. Carbon 44, 1028-1033.

Iijima, S., 1991. Helical microtubules of graphitic carbon. Nature 354, $56-59$.

Järvinen, K., Pietarinen-Runtti, P., Linnainmaa, K., Raivio, K.O., Krejsa, C.M., Kavanagh, T., Kinnula, V.L., 2000. Antioxidant defense mechanism of human mesothelioma and lung adenocarcinoma cells. Am. J. Physiol. Lung Cell Mol. Physiol. 278, 696702.

Jia, G., Wang, H., Yan, L., Wang, X., Pei, R., Yan, T., Zhao, Y., Guo, X., 2005. Cytotoxicity of carbon nanomaterials: single-wall nanotube, multi-wall nanotube, and fullerene. Environ. Sci. Technol. 39, 1378-1383.

Kagan, V.E., Tyurina, Y.Y., Tyurin, V.A., Konduru, N.V., Potapovich, A.I., Osipov, A.N., Kisin, E.R., Schwegler-Berry, D., Mercer, R., Castranova, V., Shvedova, A.A., 2006. Direct and indirect effects of single walled carbon nanotubes on RAW 264.7 macrophages: role of iron. Toxicol. Lett. 165, 88-100.

Maguire, P., Mothersill, C., Seymour, C., Lyng, F.M., 2005. Medium from irradiated cells induces dose-dependent mitochondrial changes and BCL2 responses in unirradiated human keratinocytes. Radiat. Res. 163, 384-390.

Magrez, A., Kasas, S., Salicio, V., Pasquier, N., Seo, J.W., Celio, M., Catsicas, S., Schwaller, B., Forró, L., 2006. Cellular toxicity of carbon-based nanomaterials. Nano Lett. 6, 1121-1125.

Manna, S.K., Sarkar, S., Barr, J., Wise, K., Barrera, E.V., Jejelowo, O., Rice-Ficht, A.C., Ramesh, G.T., 2005. Single-walled carbon nanotube induces oxidative stress and activates nuclear transcription factor-кB in human keratinocytes. Nano Lett. 5, 1676-1684.

Maynard, A.D., Baron, P.A., Foley, M., Shvedova, A.A., Kisin, E.R., Castranova, V., 2004. Exposure to carbon nanotube material: aerosol release during the handling of unrefined single-walled carbon nanotube material. J. Toxicol. Environ. Health A 67, 87107.

Maynard, A.D., Aitken, R.J., Butz, T., Colvin, V., Donaldson, K., Oberdörster, G., Philbert, M.A., Ryan, J., Seaton, A., Stone, V., Tinkle, S.S., Tran, L., Walker, N.J., Warheit, D.B., 2006. Safe handling of nanotechnology. Nature 144, 267-269.

Miyagawa, H., Misra, M., Mohanty, A.K., 2005. Mechanical properties of carbon nanotubes and their polymer nanocomposites. J. Nanosci. Nanotechnol. 5, 1593-1615.

Monteiro-Riviere, N.A., Inman, A.O., 2006. Challenges for assessing carbon nanomaterial toxicity to the skin. Carbon 44, 1070-1078.

Monteiro-Riviere, N.A., Nemanich, R.J., Inman, A.O., Wang, Y.Y., Riviere, J.E., 2005. Multi-walled carbon nanotubes interactions with human epidermal keratinocytes. Toxicol. Lett. 155, 377-384.

Moore, V.C., Strano, M.S., Haroz, E.H., Hauge, R.H., Smalley, R.E., Schmidt, J., Talmon, Y., 2003. Individually suspended singlewalled carbon nanotubes in various surfactants. Nano Lett. 3, 1379-1382.

Muller, J., Huaux, F., Lison, D., 2006. Respiratory toxicity of carbon nanotubes: how worried should we be? Carbon 44, 1048-1056.

Murr, L.E., Garza, K.M., Soto, K.F., Carrasco, A., Powell, T.G., Ramirez, D.A., Guerrero, P.A., Lopez, D.A., Venzor III, J., 2005. 
Cytotoxicity assessment of some carbon nanotubes and related carbon nanoparticle aggregates and the implications for anthropogenic carbon nanotube aggregates in the environment. Int. J. Environ. Res. Public Health 2, 31-42.

Oberdörster, G., Oberdörster, E., Oberdörster, J., 2005. Nanotoxicology: an emerging discipline evolving from studies of ultrafine particles. Environ. Health Perspect. 113, 823-839.

O'Reilly, J.P., Mothersill, C., 1997. Comparative effects of UV A and UV B on clonogenic survival and delayed cell death in skin cell lines from humans and fish. Int. J. Radiat. Biol. 72, 111-119.

Ozturk, S., Kaseko, G., Mahaworasilpa, A.T., Coster, H.G.L., 2003. Adaption of cell lines to serum-free culture medium. Hybrid. Hybridomics 22, 267-272.

Perez, R.P., Godwin, A.K., Handel, L.M., Hamilton, T.C., 1992. A comparison of clonogenic, microtetrazolium and sulforhodamine B assays for determination of cisplatin cytotoxicity in human ovarian carcinoma cell lines. Eur. J. Cancer 29, 395-399.

Puck, T.T., Markus, P.I., 1956. Action of X-rays on mammalian cells. J. Exp. Med. 103, 653-666.

Pulskamp, K., Diabaté, S., Krug, H.F., 2007. Carbon nanotubes shown no sign of acute toxicity but induce intracellular reactive oxygen species in dependence on contaminants. Toxicol. Lett. 168, $58-74$.

Royal Society and Royal Academy of Engineering, 2004. Nanoscience and nanotechnologies: opportunities and uncertainties. Royal Society Publications, London, available online www.royalsoc.ac.uk/policy.

Russo, A., DeGraff, W., Friedman, N., Mitchell, J.B., 1986. Selective modulation of glutathione levels in human normal versus tumor cells and subsequent differential response to chemotherapy drugs. Cancer Res. 46, 2845-2848.
Shvedova, A.A., Castranova, V., Kisin, E.R., Schwegler-Berry, D., Murray, A.R., Gandelsman, V.Z., Maynard, A., Baron, P., 2003. Exposure to carbon nanotubes material: assessment of nanotubes cytotoxicity using human keratinocyte cells. J. Toxicol. Env. Health A 66, 1909-1926.

Smart, S.K., Cassady, A.I., Lu, G.Q., Martin, D.J., 2006. The biocompatibility of carbon nanotubes. Carbon 44, 1034-1047.

Spadinger, I., Marples, B., Matthews, J., Skov, K., 1994. Can colony size be used to detect low-dose effects? Radiat. Res. 138, 21-24.

Tian, F., Cui, D., Schwarz, H., Estrada, G.G., Kobayashi, H., 2006. Cytotoxicity of single-walled carbon nanotubes on human fibroblasts. Toxicol. In Vitro 20, 1202-1212.

Van de Sandt, J., Roguet, R., Cohen, C., Esdaile, D., Ponec, M., Corsini, E., Barker, C., Fusenig, N., Liebsch, M., Benford, D., de Brugerolle de Fusenig, A., Fartasch, M., 1999. The Use of Human Keratinocytes and Human Skin Models for Predicting Skin Irritation. The Report and Recommendations of ECVAM Workshop 38, ATLA 27, pp. 723-743.

Wick, P., Manser, P., Limbach, L.G., Dettlaff-Weglikowsk, U., Krumeich, F., Roth, S., Stark, W.J., Bruinink, A., 2007. The degree and kind of agglomeration affect carbon nanotube cytotoxicity. Toxicol. Lett. 168, 121-131.

Wilson, M.R., Lightbody, J.H., Donaldson, K., Sales, J., Stone, V., 2002. Interactions between ultrafine particles and transition metals in vivo and in vitro. Toxicol. Appl. Pharmacol. 184, 172-179.

Wörle-Knirsch, J.M., Pulskamp, K., Krug, H.F., 2006. Oops they did it again! Carbon nanotubes hoax scientists in viability assays. Nano Lett. 6, 1261-1268.

Zenin, V.V., Nikolskii, N.N., Skopicheva, V.I., Sorokin, A.B., 1982. Dependence of $3 \mathrm{~T} 6$ cell proliferation on the serum concentration in the medium. Tsitologiia 24, 947-953. 